\title{
DESAIN BERKELANJUTAN DAN PELUANG PASAR EKSPOR PRODUK HOME DĖCOR INDONESIA DI JERMAN
}

\author{
Nadya Megawati Rachman ${ }^{1{ }^{*}}$, Ratnaningsih Hidayati ${ }^{1}$ \\ ${ }^{1)}$ Pusat Pendidikan dan Pelatihan Perdagangan, Kementerian Perdagangan \\ *Penulis Korespondensi: nadya.megawati@kemendag.go.id, ratna.hidayati@ kemendag.go.id
}

\begin{abstract}
Indonesian home décor products produced by Small and Medium Enterprises (SMEs) have a relatively stable export market share in Germany. This study aims to analyze the export market potential of Indonesian home décor products in the German market. and explain the concepts of integrating sustainable design into Indonesian home décor products. The research was conducted with a qualitative approach, namely by conducting desk research on data related to the export of Indonesian home décor products and also reviewing the literature on relevant sources. The results of the study show that Indonesia still has the opportunity to increase its export market share for home décor products with the HS code 462090. The recommended export marketing strategy is that SME producers should focus on middle and upper class customer segments who have a preference for sustainable designs. The government, both at the local and national levels, should also be able to support producer SMEs to be able to compete and produce home décor products with high quality and competitiveness.
\end{abstract}

Keywords: design, export, home décor, marketing, strategy

Article Information:

Received Date: 8 Februari 2022

Revised Date: 16 Februari 2022

Accepted Date: 24 Februari 2022 


\section{PENDAHULUAN}

Situasi pandemi saat ini menjadi tantangan bagi perekonomian setiap negara di dunia. Secara makro, Indonesia sendiri sempat mengalami penurunan pertumbuhan ekonomi yang drastis namun diperkirakan akan mengalami rebound pada tahun 2021. Hal positif yang terjadi selama pandemi adalah neraca perdagangan internasional non migas yang positif karena nilai impor yang lebih rendah. Angka neraca perdagangan yang positif ini harus dijaga dengan meningkatkan nilai ekspor sehingga dapat meningkatkan laju pertumbuhan ekonomi. Perkembangan perdagangan internasional Indonesia bulan April 2020 hingga April 2021 (yoy) dapat dilihat pada Gambar 1. luas di beberapa negara. Negara tujuan ekspor tradisional Indonesia adalah China, Amerika Serikat, Jepang dan negara-negara di Kawasan Eropa. Sementara itu, beberapa negara tujuan ekspor nontradisional yang potensi pasarnya sedikit atau belum tergarap, antara lain negaranegara di benua Afrika, India, Bangladesh, dan negara-negara di Kawasan Eropa Timur dan Asia Tengah yang merupakan emerging economy.

Jerman merupakan negara tujuan ekspor tradisional bagi Indonesia. Jerman mengimpor beberapa komoditas ekspor utama Indonesia yang diekspor ke Jerman adalah alas kaki, tekstil dan produk tekstil, timah, kopi dan biji kakao. Data pertumbuhan ekspor Non Migas dari Indonesia ke Jerman disajikan pada Gambar 2.

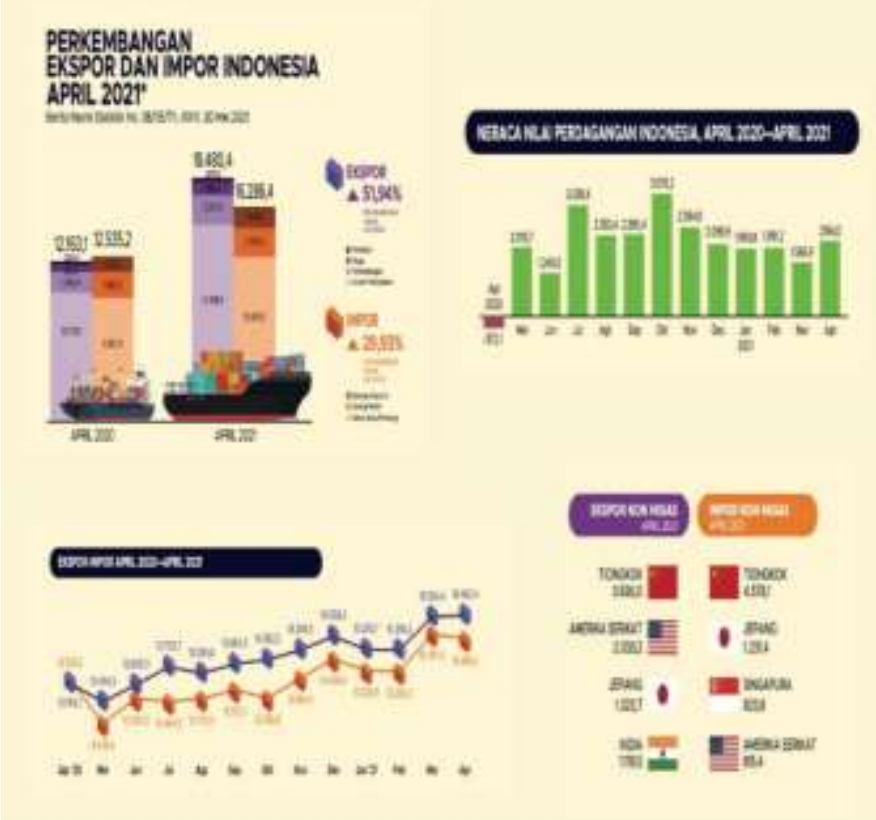

\section{Gambar 1. Infografis Neraca Perdagangan Indonesia April 2020 - April 2021 (yoy) Sumber: Badan Pusat Statistik (2021)}

Pemerintah Indonesia telah mencanangkan program pemulihan ekonomi nasional, salah satunya dengan meningkatkan nilai ekspor. Beberapa komoditas ekspor utama yang menjadi produk utama Indonesia, seperti CPO, kopi, kakao, karet, beberapa jenis logam dan mineral serta produk potensial lainnya yaitu alas kaki, memiliki pangsa pasar yang cukup

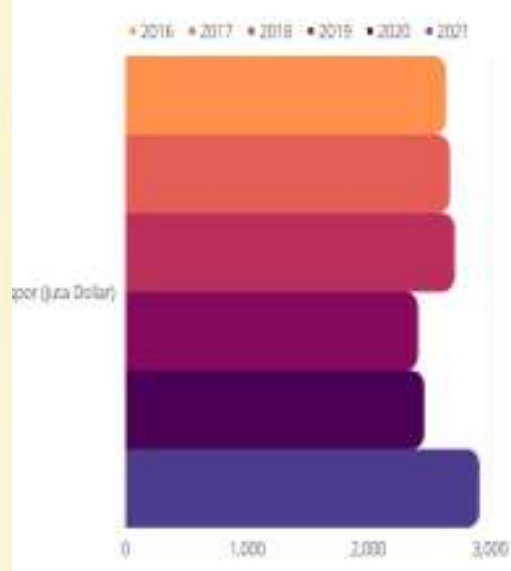

Gambar 2. Data Ekspor Non Migas dari Indonesia ke Jerman Tahun 2016 - 2021

Sumber: Badan Pusat Statistik (2021)

Tren pertumbuhan ekspor Indonesia ke Jerman mulai dari tahun 2016 hingga 2020 menurun hingga mencapai 2,41\%. Pada tahun 2020 terjadi peningkatan sebanyak $18,46 \%$ dengan pangsa $1,33 \%$ dari total ekspor Indonesia ke seluruh negara di dunia (BPS, 2021). Jerman adalah ekonomi terbesar di Eropa, dengan tingkat PDB per kapita sebesar 45,719.691 USD pada bulan Desember tahun 2020. Jerman memiliki total populasi sekitar 83.02 juta jiwa, yang merupakan $19 \%$ dari total populasi Uni Eropa. Dengan jumlah penduduk yang besar dan rata-rata pendapatan per kapita 
yang tinggi, wajar saja jika Jerman menjadi tujuan pasar ekspor bagi seluruh negara di dunia.

Tujuan dari penulisan karya tulis ilmiah ini adalah menganalisis potensi pasar ekspor produk-produk home décor Indonesia di pasar Jerman. Produk home décor dipilih karena peluang pasarnya masih besar dan relative terbuka terutama untuk produk dengan desain yang sustainable (berkelanjutan) mengikuti tren yang saat ini dan ke depannya akan menjadi gaya hidup masyarakat Jerman dan Uni Eropa pada umumnya. Selain itu, kajian ini juga bertujuan untuk menjelasakan konsepkonsep integrasi desain berkelanjutan (sustainable design) ke dalam produk-produk home décor Indonesia.

\section{METODE PENELITIAN}

Penelitian dilakukan dengan pendekatan kualitatif yaitu dengan melakukan desk research terhadap data-data terkait ekspor produk home décor Indonesia, yaitu data nilai ekspor dan data negara tujuan ekspor mulai dari tahun 2015 - 2019 serta telaah literatur yang bersumber dari berita, peraturan perundang-undangan, artikel dalam jurnal ilmiah dan sumber data serta informasi lainnya yang relevan.

\section{HASIL DAN PEMBAHASAN}

Selain komoditas ekspor utama, salah satu komoditas yang prospek ekspornya menjanjikan adalah dekorasi rumah. Dekorasi rumah adalah istilah yang mengacu pada produk yang digunakan untuk mendekorasi rumah atau interior ruangan. Dalam hal fungsionalitas dan persyaratan produk, produk dekorasi rumah berbeda dari furnitur.

Secara umum, di Eropa telah terjadi kecenderungan peningkatan impor produkproduk home décor. Beberapa produk home décor di pasar Eropa bersumber dari negara berkembang. Peluang pasar sangat besar, terutama untuk segmen kalangan berpenghasilan menengah ke atas. Membidik segmen premium ini adalah teknik untuk menghindari persaingan dari negara-negara yang mampu memproduksi massal dengan harga yang relatif rendah.

Produk-produk home décor yang diimpor dari Indonesia Sebagian besar diproduksi oleh Usaha Kecil dan Menengah (UKM). Menurut Undang Undang no. 20 tahun 2008 UKM didefinisikan sebagai usaha perorangan atau badan usaha yang telah melakukan kegiatan usaha yang memiliki aset tidak lebih dari Rp. 500.000.000 dan omzet pertahun tidak lebih dari 2,5 milyar. Apabila salah satu dari omzet ataupun asset melebihi dari itu, maka bisa dikatakan usaha menengah namun tidak lebih dari 10 miliar untuk aset dan 50 milyar untuk omzet.

UKM merupakan tulang punggung perekonomian negara. Pada tahun 2019, sebanyak 99 persen unit usaha di Indonesia merupakan Usaha Mikro, Kecil dan Menengah yang menyerap tenaga kerja sekitar 96.7 persen dari total tenaga kerja di Indonesia. Akan tetapi, kontribusi ekspor non migas dari kelompok usaha ini hanya sekitar 15.65 persen (Kementerian Koperasi dan UKM Republik Indonesia, 2021). Hal ini berarti Sebagian besar UMKM di Indonesia masih berorientasi pada pasar domestik.

Pasar interasional merupakan pasar yang sangat potensial untuk produk-produk home décor Indonesia. Namun demikian, risiko yang dihadapi oleh UKM produsen produk home décor ini juga semakin tinggi karena ketidakpastian yang diakibatkan oleh jarak pengiriman barang dan mekanisme transaksi antarnegara. Keberadaan mitra bisnis yang andal adalah kebutuhan utama untuk mengatasi keterbatasan sumber daya yang dimiliki UKM dalam melakukan internasionalisasi bisnisnya (Mort, 2012 dalam Hatmawan, 2020). Kolaborasi dengan mitra bisnis eksternal akan memberikan akses lebih kepada pengetahuan, teknologi dan sumber daya eksternal lainnya, sehingga proses research and development (R\&D) dapat lebih dipersingkat 
UKM perlu untuk meningkatkan kompetensi kontekstual mereka dan menyesuaikannya dengan pasar di luar negeri dalam memasuki pasar ekspor (Khanna, 2015). Orientasi kewirausahaan, kemampuan jaringan dan inovasi merupakan factor-faktor yang berpengaruh positif dan signifikan pada kinerja UKM di pasar internasional. Artinya, semakin tinggi orientasi kewirausahaan, kemampuan jaringan bisnis serta inovasi, maka kinerja ekspor UKM akan semakin meningkat. (Hatmawan, 2020) Saat ini pemasaran produk secara online merupakan tren baru yang terus berkembang dan dimanfaatkan oleh pelaku UKM di Indonesia. Kemampuan melakukan pemasaran secara online dan ketersediaan informasi pasar melalui internet terbukti berpengaruh secara positif terhadap pertumbuhan pasar ekspor. (RAHMADANI, 2018).

Oleh karena itu, pelaku UKM yang bermaksud untuk memperluas pemasaran produknya ke pasar ekspor haruslah memiliki komitmen, pengetahuan tentang teknologi dan strategi pemasaran online serta jejaring kemitraan bisnis yang kuat. Peran pemerintah baik di tingkat local maupun nasional sangatlah penting. Pemerintah dapat merancang program-program yang dapat mendukung pengembangan dan kesuksesan UKM untuk memperluas pasar internasional. UKM pelaku ekspor pemula biasanya akan menghadapi berbagai hambatan karena jarak fisik, risiko dan ketidakpastian. (Knight and Liesch, 2016) Perusahaan yang menggunakan pameran dagang yang disponsori oleh pemerintah negara bagian cenderung memiliki hasil kinerja ekspor yang positif. (Wilkinson and Brouthers, 2006)

Kunci sukses UKM untuk sukses dan bertahan adalah: kemampuan untuk menciptakan produk,yang berbeda dengan yang sudah ada di pasar, membidik segmen pasar, menciptakan citra merek, menemukan ceruk pasar dan menargetkan kelompok pelanggan tertentu. (Charbonneau and Menon, 2013). Selain itu disebutkan pula bahwa Karakteristik dan kompetensi perusahaan seperti ukuran perusahaan, pengetahuan tingkat teknologi, dan lain-lain serta kemampuan strategis pemasaran ekspor seperti pemanfaatan riset pemasaran internasional, segmentasi dan targetting, kapabilitas produk, dan lain-lain juga memainkan peran sentral dalam kinerja ekspor UKM (Nazar and Saleem, 2009).

Sebuah penelitian sebelumnya menyebutkan bahwa inovasi produk merupakan salah satu kunci sukses UKM dalam menembus pasar ekspor.(Sui and Baum, 2014) Strategi pemasaran produk UKM yang terdiversifikasi, dalam konteks produk dan pasar memiliki hubungan yang positif dengan kinerja ekspor.(Dikova et al., 2016). Produk-produk home décor Indonesia harus memiliki strategi pemasaran yang tepat untuk menembus pasar internasional, khususnya di negara Jerman.

Salah satu bauran pemasaran (Marketing Mix) yang dapat diterapkan dalam rangka memperluas pasar ekspor adalah strategi produk (products) yaitu dengan merancang desain-desain yang inovatif dan berkelanjutan (innovative sustainable design). Desain berkelanjutan (sustainable design) adalah area kompleks yang mengintegrasikan berbagai kriteria lingkungan, sosial dan ekonomi. Terdapat beberapa strategi desain yang mengintegrasikan elemen tanggung jawab social pada desain berkelanjutan untuk produkproduk furniture yaitu: desain untuk melindungi HAM, desain untuk terwujudnya praktik perburuhan yang adil (fair labor practices), desain untuk operasional perusahaan yang adil (fair operational practices), desain untuk berbagai isu konsumen, desain untuk keterlibatan dan pegembangan komunitas local. (Vicente, Frazão and da Silva, 2017)

Penggunaan desain berkelanjutan ini, terutama untuk produk furnitur saat ini masih mengalami berbagai kendala yaitu pengetahuan yang terbatas tentang prinsipprinsip desain berkelanjutan di antara tim desain, kurangnya kesadaran tentang keberlanjutan di antara pembeli furnitur, 
kurangnya visi yang jelas untuk masa depan industri furnitur yang keberlanjutan, kurangnya pemikiran strategis, dan kelemahan dalam memahami undang-undang hak cipta (Valipoor and Ujang, 2011)

Pandemi virus corona dan respons global terhadapnya berdampak signifikan pada perdagangan internasional dan pasar Eropa untuk berbagai macam barang dan jasa, seperti produk-produk home decor. Pandemi diperkirakan akan berdampak pada permintaan barang-barang home décor, tetapi tingkat dampaknya akan bervariasi menurut kategori produk. Respon mental konsumen umumnya menurun akibat pandemi. Terlepas dari masalah kesehatan mereka, pelanggan khawatir tentang prospek pekerjaan mereka dan sejauh mana mata pencaharian mereka akan terancam. Hal ini jelas tidak akan meningkatkan penjualan ekspor. Jaringan distribusi sektor ini juga terkena dampak negatif, karena banyak pengecer tradisional (brick and mortar retailer) terpaksa tutup karena produk ini dianggap sebagai barang 'tidak esensial', dan yang lainnya mungkin tidak dapat bertahan dari krisis secara finansial.

Jerman adalah ekonomi terbesar di Eropa, yang berkontribusi pada 19\% dari populasi Uni Eropa. Ekonomi Jerman secara luas dianggap sebagai kekuatan penstabil di dalam Uni Eropa, secara tradisional mengungguli negaranegara anggota lainnya dalam hal pertumbuhan. The Economist memprediksi bahwa Jerman akan menjadi negara pertama yang keluar dari krisis saat ini di Eropa. Asumsi ini difokuskan pada keuangan negara yang sehat sebelum krisis dan sektor manufaktur yang cukup besar, yang juga akan mendukung pemasok asing.

Seiring dengan pasar domestik yang cukup besar, Jerman merupakan pusat perdagangan penting di seluruh Eropa. Pada tahun 2019, negara tersebut mengekspor produk Home Décor dan Home Textile (HDHT) senilai lebih dari $€ 20$ miliar, terutama ke negara-negara Eropa lainnya. Dikombinasikan dengan permintaan yang cukup besar untuk negara berkembang dan antisipasi pemulihan ekonomi yang, Jerman menghadirkan pasar yang menarik untuk produk home décor Indonesia.

Negara-negara di Eropa Barat yang lebih besar skala ekonominya merupakan importir utama produk-produk home décor. Importir di negara-negara ini, di sisi lain, biasanya memasarkan barang-barang mereka di seluruh Eropa, tidak hanya di negaranya sendiri. Dengan demikian, pendekatan terbaik adalah berkonsentrasi pada segmen tertentu daripada wilayah tertentu.

Di sisi lain, pandemi telah membangunkan kesadaran konsumen dunia dan Eropa akan pentingnya aspek kesehatan dan keberlanjutan. Selain itu, muncul tren baru di kalangan milenial di Eropa, yaitu kehidupan komunal, sebagai dampak dari pesatnya arus urbanisasi.

Tumbuhnya kepedulian terhadap kesehatan di Jerman atau Eropa pada umumnya telah muncul sejak lama. Hal itu semakin populer karena orang-orang berusaha mengelola ketegangan kehidupan sehari-hari mereka yang sibuk. Preferensi konsumen untuk dekorasi rumah mencerminkan keinginan untuk gaya hidup yang lebih aman, bahagia, dan seimbang. Misalnya, dengan lebih terlibat dengan alam adalah metode yang populer untuk meningkatkan kesejahteraan. Konsumen dapat melakukannya dengan membawa tanaman ke rumah mereka dan memilih produk HDHT yang menggabungkan bahan, desain, dan bentuk alami. Kategori produk home décor mencakup berbagai barang yang dapat digunakan untuk mengubah rumah menjadi tempat yang sempurna untuk menghilangkan ketegangan dan melepas lelah - baik sebelum maupun setelah pandemi.

Terkait keberlanjutan, ide daur ulang (recycling) dan perbaikan (upcycling) sangat umum di pasar Eropa. Alih-alih mengkonsumsi lebih sedikit, masyarakat Eropa cenderung ingin melakukan konsumsi dengan lebih bijaksana. Generasi milenial berkomitmen untuk membuat dunia menjadi tempat yang lebih baik, dan sementara itu generasi baby 
boomer juga tertarik untuk berkontribusi. Hal ini memunculkan urgensi dan pengaruh pasar dalam industri HDHT,. Konsumen di Eropa semakin menuntut agar produsen harus menyediakan kesempatan yang sama untuk setiap pekerja, sehingga semua pekerja mendapatkan upah layak, dan bekerja dalam kondisi yang layak.

Milenial memberikan pengaruh yang signifikan pada beberapa aspek kehidupan sosial dan profesional. Pemasaran telah berkembang menjadi domain milenial, yang dipengaruhi oleh influencer media sosial. Generasi ini membentuk idealism dan nilainilai kehidupan yang baru baru, seperti 'berbagi lebih baik daripada memiliki'. Mereka menganggap rumah mereka sebagai perpanjangan dari karakter mereka, atau setidaknya kepribadian yang mereka citacitakan.

\section{PASAR PRODUK HOME DÉCOR DI JERMAN DAN EROPA}

Berbagai produk home décor Indonesia diproduksi oleh Usaha Kecil Menengah (UKM). Misalnya, barang dekorasi rumah dengan kode HS 462090, yaitu keranjang, anyaman, dan barang lainnya yang dibuat langsung dari bahan anyaman non-sayuran, memiliki prospek pasar yang cerah di pasar Eropa. Keranjang tersebut berada di bawah judul heading 'penyimpanan' pada kategori produk home décor. Keranjang tersebut digunakan untuk menyimpan barang-barang lepas dan menjaga kebersihan rumah. Terlepas dari tujuan utilitariannya, keranjang telah berevolusi menjadi barang dekoratif dengan caranya sendiri. Kadang-kadang, nilai dekoratif mereka melebihi peran utama mereka sebagai alat penyimpan.

Dalam beberapa tahun terakhir, pasar keranjang Eropa telah berkembang. Sekitar tiga perempat volume impor berasal dari negara maju. Mayoritas keranjang impor ini seluruhnya terbuat dari bahan alami. Antara 2015 dan 2019, impor keranjang Eropa meningkat 4,3 persen per tahun, dari €467 juta menjadi €552 juta. Antara 2015 dan 2019, negara-negara berkembang menyumbang sekitar tiga perempat dari jumlah keseluruhan impor keranjang Eropa

\section{Gambar 3. Grafik Perkembangan impor produk home décor berupa keranjang di Eropa}

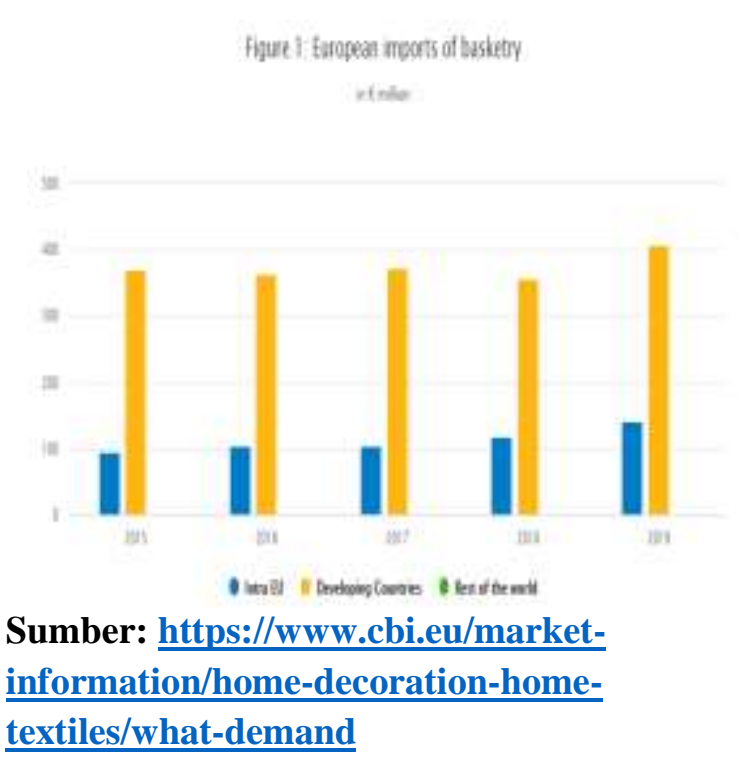

Jerman adalah importir produk home décor berupakeranjang terbesar di Eropa pada tahun 2019. Jerman memimpin dengan $18 \%$ dari total impor, diikuti oleh Inggris (14\%), Prancis (13\%), dan Belanda (12\%). Negara-negara ini menyumbang lebih dari setengah dari total di Eropa. Spanyol (9,1 persen) dan Italia $(9,1$ persen) adalah pasar yang lebih kecil dengan

pangsa kurang dari $10 \%$, tetapi tetap berada di enam negara pengimpor terkemuka $(5,6$ persen).

Sekitar tiga perempat nilai impor Jerman berasal dari negara berkembang. Nilai impor ini sempat menurun dari $€ 87$ juta pada tahun 2015 dan menjadi $€ 74$ juta pada tahun 2019 . Namun, penurunan ini terutama disebabkan oleh penurunan impor dari China, yang merupakan pemasok keranjang untuk home décor terbesar dunia. Impor Jerman dari negara berkembang lainnya, termasuk Vietnam dan Indonesia, relatif stabil dengan nilai sekitar $€ 32$ juta. Artinya, Indonesia memiliki banyak 
peluang untuk mengisi pangsa pasar impor yang tadinya diisi oleh produk home décor dari Cina.

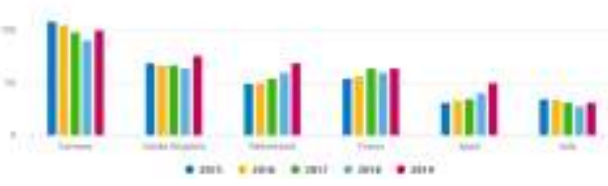

\section{Gambar 4. Negara-negara importir terbesar produk home décor berupa keranjang Sumber: https://www.cbi.eu/market- information/home-decoration-home- textiles/what-demand}

Menurut The Economist, Jerman akan menjadi ekonomi besar Eropa pertama yang pulih dari krisis saat ini,. Asumsi ini difokuskan pada keuangan negara yang sehat sebelum krisis dan sektor manufaktur yang cukup besar. Hal ini tentu akan menguntungkan bagi pemasok asing. Seiring dengan pasar domestik yang cukup besar, Jerman merupakan pusat perdagangan penting di seluruh Eropa. Jika dipadukan dengan pasar yang kompetitif bagi negara berkembang dan prospek pertumbuhan ekonomi, Jerman menghadirkan peluang yang menarik bagi Indonesia.

\section{ANALISIS SWOT}

\section{Kekuatan dan Kelemahan (Strengths and Weaknesses)}

Sebagian besar produk home décor Indonesia berupa keranjang diproduksi oleh Usaha Kecil Menengah. UKM sangat fleksibel dalam hal desain dan produksi. Tersedianya bahan baku yang melimpah dan sumber daya manusia yang terampil untuk produksi, karena proses produksi yang tidak canggih dan tenun telah menjadi budaya Indonesia yang diwarisi dari generasi sebelumnya. Beberapa perusahaan juga memiliki pasar ekspor di Amerika Serikat sehingga mereka memiliki pengetahuan sebelumnya tentang standar dan pasar internasional.

Keranjang Indonesia yang diproduksi oleh UKM memiliki peluang besar di Eropa.
Namun demikian, UKM harus meningkatkan pengetahuan dan keterampilan mereka di pasar Eropa. Produsen dekorasi rumah seperti banyak UKM lainnya biasanya dikelola secara tradisional. Banyak UKM memiliki manajemen arus kas yang buruk, dan karena situasi pandemi, dilaporkan bahwa UKM juga berjuang dengan arus kas yang menurun. Dari sisi sumber daya manusia, saat ini masih kurangnya personel yang melek digital untuk menangani komunikasi pemasaran dengan pelanggan di luar negeri. Pengetahuan Digital sangat penting dalam situasi ini. Saat ini pameran dagang kemungkinan besar akan diselenggarakan secara online oleh karena itu UKM harus lebih memperhatikan tampilan produk digital.

\section{Peluang dan Tantangan (Opportunities and Threats)}

Pemerintah Indonesia memberikan dukungan kuat bagi UKM produsen barang-barang home décor untuk memperluas pasar internasional mereka. Meskipun situasi sulit selama wabah virus corona, terdapat beberapa peluang pembiayaan dari pemerintah atau badan usaha milik negara untuk meningkatkan kapasitas produksi. Selain itu, UKM dapat berpartisipasi dalam pameran perdagangan virtual yang lebih murah dan menciptakan peluang bisnis. Ada juga peluang ceruk pasar baru bagi generasi milenial yang sangat peduli dengan keberlanjutan.

Pandemi Covid-19 masih menjadi tantangan besar bagi bisnis internasional. Produk home décor berupa keranjang dari Indonesia menghadapi persaingan ketat dari negara lain terutama China yang mampu membuat produk massal dengan cara yang lebih murah. Selain itu, UKM harus mematuhi standar dan peraturan UE mengenai desain berkelanjutan. Terdapat beberapa peraturan untuk melakukan ekspor ke pasar Eropa. UKM harus mematuhi beberapa regulasi dan undang-undang yang deberlakukan untuk semua produk home décor , persyaratan lainnya adalah persyaratan nonlegislasi (diutamakan oleh pembeli). 
Persyaratan perundang-undangan adalah General Product Safety Directive dan REACH; General Product Safety Directive (Petunjuk Keamanan Produk Umum Eropa) menyatakan bahwa semua produk yang dipasarkan di Eropa harus aman digunakan. Peraturan ini memberikan kerangka kerja untuk semua undang-undang mengenai produk dan masalah tertentu. REACH mencantumkan bahan kimia terlarang dalam produk yang dipasarkan di Eropa. REACH (EC 1907/2006) bertujuan untuk meningkatkan perlindungan kesehatan manusia dan lingkungan melalui identifikasi sifat-sifat zat kimia yang lebih baik dan lebih dini. Untuk keranjang, bahan kimia terutama digunakan dalam pewarna dan cat. Eropa memiliki undang-undang pengemasan dan limbah pengemasan khusus. The EU Directive 2015/720 diadopsi untuk menyelaraskan langkah-langkah di level Eropa terkait pengelolaan kemasan dan limbah kemasan serta untuk mencegah atau mengurangi dampaknya terhadap lingkungan.

Persyaratan non-undang-undang untuk produk home décor yang disukai pelanggan adalah Business Social Compliance Initiative (BSCI). BSCI adalah inisiatif yang dikembangkan oleh pengecer Eropa untuk meningkatkan kondisi sosial di negara-negara sumber. Mereka mengharapkan pemasok mereka untuk mematuhi Kode Etik BSCI.

Pelanggan seringkali membutuhkan dokumen untuk memastikan produk dekorasi rumah yang dibeli diproduksi secara berkelanjutan. Sertifikat ISO 14001 telah direkognisi sebagai standar kualitas lingkungan. Standar ini berguna untuk memberikan gambaran bagi opsi berkelanjutan. Persyaratan lain yang disukai pembeli adalah sertifikat Fair Trade (Perdagangan yang Adil). Konsep perdagangan yang adil ini mendukung penetapan harga yang adil dan meningkatkan kondisi sosial bagi produsen dan komunitas di sekitarnya.

\section{SUSTAINABLE DESIGN BERKELANJUTAN)}

Terdapat kecenderungan di antara negaranegara Eropa Barat untuk lebih memperhatikan keberlanjutan dalam setiap aspek produk yang mereka konsumsi. Sebagaimana dinyatakan dalam Tujuan Pembangunan berkelanjutan (Sustainable Development Goals) PBB, pembangunan berkelanjutan dimaksudkan untuk memenuhi kebutuhan saat ini tanpa mengorbankan kemampuan generasi mendatang untuk memenuhi kebutuhan mereka sendiri. John Elkington menciptakan "Triple Bottom Line" dari People, Planet, dan Profit sebagai kerangka model keberlanjutan. Triple bottom line mengkaji dampak sosial, lingkungan, dan ekonomi perusahaan. Andy James dan John A. Dutton (2021) menjelaskan beberapa variasi model keberlanjutan seperti yang ditunjukkan pada Tabel 1 .

Table 1. Model-Model Keberlanjutan

\begin{tabular}{|l|l|l|l|}
\hline Model & $\begin{array}{l}\text { "Planet" } \\
\text { adalah: }\end{array}$ & $\begin{array}{l}\text { "People" } \\
\text { adalah: }\end{array}$ & $\begin{array}{l}\text { "Profit" } \\
\text { adalah: }\end{array}$ \\
\hline $\begin{array}{l}\text { Triple } \\
\text { Bottom Line } \\
\text { (Savitz } \\
\text { adaptation of } \\
\text { Elkington, } \\
\text { 2006) }\end{array}$ & $\begin{array}{l}\text { Kepentingan } \\
\text { masyarakat } \\
-\end{array}$ & $\begin{array}{l}\text { Kepentingan } \\
\text { masyarakat - } \\
\text { Aspek sosial }\end{array}$ & $\begin{array}{l}\text { Kepentingan } \\
\text { bisnis }\end{array}$ \\
\hline $\begin{array}{l}\text { Sustainability } \\
\text { "Sweet Spot" } \\
\text { (Farver, } \\
\text { 2013) }\end{array}$ & $\begin{array}{l}\text { Kepedulian } \\
\text { lingkungan }\end{array}$ & $\begin{array}{l}\text { Kesejahteraan } \\
\text { Sosial }\end{array}$ & $\begin{array}{l}\text { Kesejahteraan } \\
\text { Ekonomi }\end{array}$ \\
\hline $\begin{array}{l}\text { B } \\
\text { Corporation } \\
\text { Impact } \\
\text { Assessment } \\
\text { (Honeyman, } \\
\text { 2014) }\end{array}$ & Baik untuk & Baik untuk \\
para pekerja & $\begin{array}{l}\text { Baik untuk } \\
\text { jangka waktu } \\
\text { yang panjang }\end{array}$ \\
\hline
\end{tabular}

Source: James and Dutton (2021).

Menurut CBI (2011), produk yang memilik desain berkelanjutan adalah produk yang menyenangkan secara estetika, memiliki identitas yang berbeda, dan mudah digunakan. Barang-barang ini sepenuhnya menggabungkan aspek sosial dan lingkungan di seluruh siklus hidupnya, mulai dari manufaktur hingga penggunaan dan pembuangan. Pertimbangan lingkungan 
penting ketika mengembangkan barang yang berkelanjutan. Produk yang dibuat dari sumber daya yang tumbuh secara organik dan/atau terbarukan, serta produk yang dibuat dari bahan daur ulang atau baru, lebih disukai oleh pelanggan Eropa. Barang-barang home décor harus diproduksi dengan cara yang lebih ramah lingkungan (lebih sedikit limbah, lebih sedikit energi) dan lebih ramping (lebih cepat, lebih ringan, dan lebih sedikit transportasi).

Aksis kedua dari desain lingkungan adalah aksis sosial. Desain berkelanjutan membutuhkan penekanan kuat pada rekayasa aspek sosial. Produk home décor tersebut harus dapat memberikan keuntungan/manfaat yang adil untuk semua aktor dalam rantai nilai dalam hal manfaat sosial dan budaya. Produk home dedor harus dibuat sesuai dengan praktik perdagangan yang adil, yang berarti barang tersebut harus dibuat oleh produsen secara terbuka dan melibatkan pemasok yang berinvestasi di komunitas mereka. Selain itu, untuk barang-barang yang dibuat oleh anggota kelompok yang terpinggirkan (seperti penyandang disabilitas) dan minoritas harus memiliki tempat pada rantai nilai produk home décor. Dimensi sosial meliputi pelestarian budaya asli. Produk yang dibuat untuk melestarikan dan memajukan keterampilan dan teknik asli serta mematuhi standar desain lingkungan merupakan bagian dari strategi desain berkelanjutan.

Pasar desain berkelanjutan untuk produk home décor, yang saat ini dianggap sebagai pasar khusus, diyakini akan tumbuh secara signifikan di tahun-tahun mendatang. Produk dekorasi rumah yang dirancang secara berkelanjutan dapat menjadi peluang bagi Indonesia jika produk tersebut menarik bagi konsumen Eropa, yang sangat sadar akan desain di semua segmen pasar. Pabrikan harus dapat menunjukkan bahwa proses manufaktur mereka bersih (lebih hijau), terbuka, dan bermanfaat bagi semua pemangku kepentingan rantai nilai. Konsumen harus mendapatkan informasi tentang efisiensi dan kredensial barang home décor, serta proses manufaktur harus diikuti oleh narasi yang melibatkan konsumen secara rasional maupun emosional.

\section{STRATEGI KEBERLANJUTAN DAN PEMASARAN EKSPOR UNTUK PRODUK HOME DÉCOR INDONESIA}

Perluasan pasar ekspor berarti melibatkan risiko dan upaya yang lebih besar serta mungkin memerlukan sumber daya keuangan yang lebih besar, terutama untuk Usaha Kecil Menengah yang biasanya kurang memiliki akses ke informasi tentang pasar dan tren global. Seperti disebutkan sebelumnya, terdapat peluang pasar yang besar untuk produk-produk home décor di Jerman yang sebagian besar didominasi oleh China dengan produk massal yang diposisikan untuk memenuhi segmen pasar dengan pendapatan rendah.

Indonesia harus menerapkan strategi pemasaran blue ocean strategy untuk menghindari persaingan yang ketat dengan China dan Vietnam. Usaha Kecil dan Menengah UKM harus dilatih untuk menghasilkan produk unggulan dan berkualitas premium yaitu produk home décor yang dirancang dengan baik secara berkelanjutan. Produk tersebut harus diposisikan untuk segmen pelanggan kelas menengah dan atas yang mencari kualitas premium dan desain yang berkelanjutan. UKM harus membangun jaringan distributor yang kuat di salah satu negara Eropa, terutama Jerman sebagai kantor pusat atau salah satu negara EFTA yang memiliki Perjanjian Perdagangan Bebas dengan Indonesia untuk memastikan kualitas produk memenuhi harapan pelanggan.

Dalam hal promosi, sebaiknya produsen home décor Indonesia menggunakan media sosial sebagai strategi komunikasi dengan konsumen untuk menjaga product image awareness. Pameran internasional baik fisik maupun virtual tetap menjadi metode paling efektif untuk menampilkan produk dekorasi rumah dan mengungkapkan kualitas premiumnya kepada pembeli. Cara lain untuk mempromosikan produk adalah bekerja sama 
dengan Atase Perdagangan dan ITPC dan menampilkan produk di kantor ITPC dan KBRI di seluruh Eropa.

Di pasar Uni Eropa, perdagangan yang adil adalah masalah yang kerap menjadi sorotan. Akibatnya, perusahaan produsen produk home décor harus menginvestasikan lebih banyak sumber daya dalam membangun hubungan yang baik antara semua pelaku dalam rantai nilai, mulai dari pemasok, karyawan, dan pelanggan akhir di negara-negara Uni Eropa. Selain itu, semua pemangku kepentingan harus memastikan bahwa perdagangan di antara mereka cukup diuntungkan. Narasi tentang tradisi dan hubungan yang adil dalam proses perdagangan, akan menciptakan hubungan emosional antara produk dan konsumen. Cerita ini akan menjadi nilai tambah bagi produk home décor untuk pangsa pasar premium.

Produk yang dirancang secara berkelanjutan harus mengelaborasi tiga elemen penting yaitu profit, people, dan planet. Indonesia memiliki bahan baku yang melimpah untuk pembuatan produk home décor, tetapi produsen harus memprioritaskan pelestarian ekosistem untuk generasi berikutnya dalam memenuhi kebutuhan mereka selain juga memaksimalkan keuntungan dari penghematan biaya, skema pembayaran upah yang adil untuk semua karyawan. Desain yang berkelanjutan mengintegrasikan konsep keadilan perdagangan, memastikan bahwa semua pemain dalam rantai nilai harus mendapatkan keuntungan yang adil secara merata dari perdagangan produk home décor ini.

Manfaat produk berkelanjutan yang diperluas untuk semua pemangku kepentingan harus dijadikan sebagai focus utama dalam proses manufaktur dan distribusi. Keterlibatan komunitas lokal serta perempuan tanpa pekerjaan formal dan penyandang disabilitas untuk menghasilkan produk home décor akan menciptakan cerita yang kuat yang akan menambah nilai produk karena konsumen premium biasanya membeli produk berdasarkan nilai daripada harga dari produk itu sendiri.
Perusahaan produsen barang-barang home décor harus konsisten dalam upaya mereka untuk memproduksi produk dekorasi rumah yang ramah lingkungan dan biodegradable untuk pasar Eropa. Produk tidak boleh mengandung zat berbahaya bagi lingkungan dan harus terdegradasi secara alami sampai produk itu tidak lagi dibutuhkan. Strategi planet ini juga harus dilengkapi dengan inovasi desain yang berkelanjutan agar tetap relevan dalam lingkungan bisnis yang dinamis saat ini.

\section{KESIMPULAN DAN REKOMENDASI}

Produk-Produk home décor Indonesia memiliki peluang pasar yang cukup besar di Eropa. Walaupun Indonesia menghadapi persaingan dari negara-negara berkembang Asia seperti Cina, Vietnam, dan Bangladesh, permintaan untuk produk dekorasi rumah tumbuh secara bertahap, dan Indonesia harus fokus pada pelanggan kelas menengah dan atas yang memiliki preferensi terhadap desain yang berkelanjutan.

Perluasan pasar ekspor produk home decor ke Eropa merupakan proses berkelanjutan yang melibatkan seluruh pemangku kepentingan, termasuk produsen, konsumen, dan pelanggan, serta perwakilan perdagangan Indonesia di luar negeri. Atase perdagangan dan Pusat Promosi Perdagangan Indonesia (ITPC) memainkan peran penting. Mereka harus mengambil peran aktif dalam promosi dan diplomasi perdagangan.

Indonesia dan Uni Eropa saat ini sedang merundingkan Perjanjian Kemitraan Ekonomi Komprehensif (Indonesia-EU CEPA). Masa pandemi ini merupakan momentum bagi percepatan perundingan bagi kedua belah pihak. Sehingga diharapkan nantinya ketika perjanjian kerja sama ekonomi tersebut telah disepakati, kondisi ekonomi telah pulih dan Indonesia akan memperoleh akses pasar yang lebih besar untuk perdagangan produk home décor di pasar Jerman dan pasar Eropa pada umumnya. Berdasarkan hasil penelitian, rekomendasi yang diberikan adalah meningkatkan produksi dengan desain-desain 
yang inovatif dan sustainable dengan kualitas yang memenuhi standar pasar Jerman dan pasar Uni Eropa pada umumnya.

\section{REFERENSI}

Badan Pusat Statistik, 2021, https://bps.go.id

CBI Market Information, 2021, Exporting home decoration and home textiles to Europe, https://www.cbi.eu/marketinformation/home-decoration-hometextiles

Charbonneau, J. and Menon, H. (2013) 'A strategic approach to SME export growth', in International Trade Forum. International Trade Centre, p. 32.

Dikova, D. et al. (2016) 'What is beneficial for first-time SME-exporters from a transition economy: A diversified or a focused export-strategy?', Journal of World Business. Elsevier, 51(2), pp. 185-199.

Hatmawan, A. A. (2020) 'Analisis faktor yang mempengaruhi kinerja UKM di pasar internasional', Jurnal Ekonomi Modernisasi, 16(1), pp. 1-18.

James and Dutton (2021). Sustainability Driven Innovation. E-Course from John Dutton e-Education Institute. College of Earth and Mineral Sciences at The Pennsylvania State University. https://www.e-

education.psu.edu/ba850/ last accessed on March 29, 2021

Kementerian Koperasi dan UKM Republik Indonesia (no date) Data UMKM 2018-2019, 2021. Available at: https://kemenkopukm.go.id/uploads/la poran/1617162002_SANDINGAN_D ATA_UMKM_2018-2019.pdf (Accessed: 6 June 2021).

Khanna, T. (2015) 'A case for contextual intelligence', Management International Review. Springer, 55(2), pp. 181-190.

Knight, G. A. and Liesch, P. W. (2016) 'Internationalization: incremental to born global', Journal of World Business. Elsevier, 51(1), pp. 93-102.

Nazar, M. S. and Saleem, H. M. N. (2009) 'Firm-level determinants of export performance', International Business \& Economics Research Journal (IBER), 8(2).

RAHMADANI, P. (2018) 'PENGARUH INTERNET MARKETING PADA PERTUMBUHAN EKSPOR UKM DI INDONESIA', ETD Unsyiah.

Sui, S. and Baum, M. (2014) 'Internationalization strategy, firm resources and the survival of SMEs in the export market', Journal of International Business Studies. Springer, 45(7), pp. 821-841.

Valipoor, S. and Ujang, B. (2011) 'Challenges of sustainable design in Malaysian furniture industry', in 2011 International conference on environment and industrial innovation, IACSIT Press, Singapore.

Vicente, J., Frazão, R. and da Silva, F. M. (2017) 'Sustainable product design and the wood furniture sector', in International Conference on Applied Human Factors and Ergonomics. Springer, pp. 762-772.

Wilkinson, T. and Brouthers, L. E. (2006) 'Trade promotion and SME export performance', International Business Review. Elsevier, 15(3), pp. 233-252. 